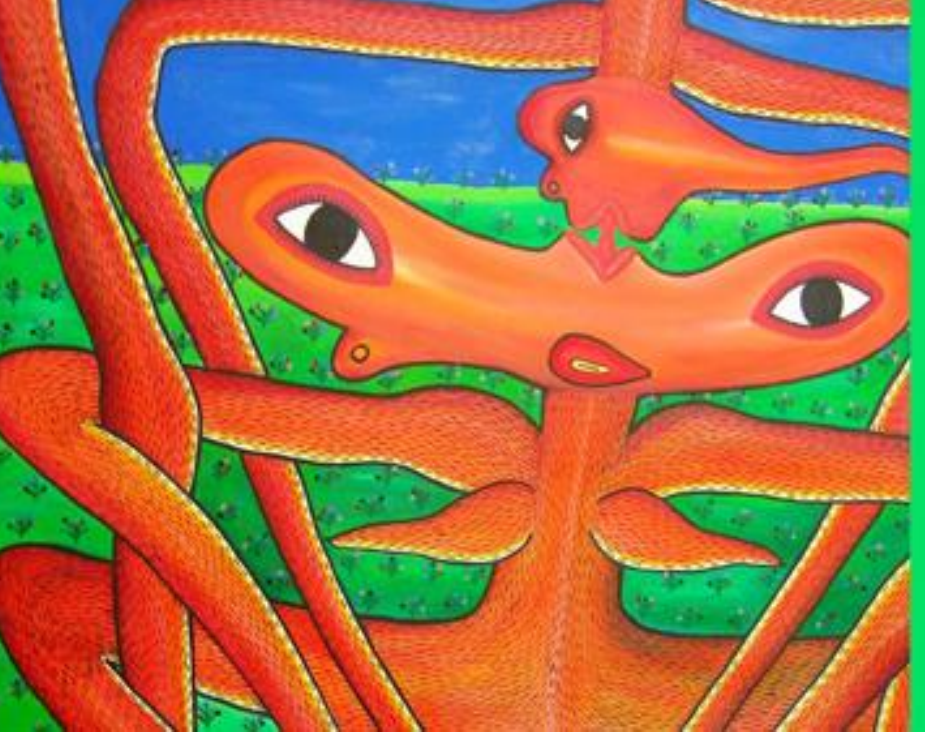

\title{
TENDA DOS MILAGRES: O INTELECTUAL NEGRO E A MILITÂNCIA CONTRA A ELITE RACISTA
}

\author{
TENT OF MIRACLES: THE INTELLECTUAL BLACK AND \\ THE MILITANCE AGAINST RACIST ELITE
}

\author{
Aline Santos de Brito NASCIMENTO \\ UNIVERSIDADE DO ESTADO DA BAHIA, Brasil
}

RESUMO | INDEXAÇÃO | TEXTO | REFERÊNCIAS | CITAR ESTE ARTIGO | A AUTORA RECEBIDO EM 14/12/2017 • APROVADO EM 05/04/2018

\section{Resumo}

Tenda dos milagres, de Jorge Amado, é aqui analisada e fundamentada a partir da discussão acerca dos intelectuais negros e sua produção, da crítica pós-colonial acerca da identidade negra, e do trabalho intelectual de militância. A metodologia da pesquisa, qualitativa, incluiu a análise de conteúdo e de discurso, e método indutivo. O texto aborda o personagem que se torna escritor, Pedro Anchanjo, e seu adversário intelectual, Nilo Argolo, médico conhecido pelas ideias carregadas de preconceito. Os resultados apontam que as obras de Archanjo, mestiço, pobre, só são reconhecidas a partir do interesse de Levenson, estrangeiro renomado. Seus livros retratam principalmente um trabalho de militância contra o preconceito, a violência e a intolerância dos brancos diante dos rituais de origem africana. 
Tent of miracles, of Jorge Amado, is here analyzed and justified from the discussion of black intellectuals and their production, post-colonial criticism about black identity, and intellectual militancy work. The research methodology, qualitative, included content and discourse analysis, and inductive method. The text addresses the character who becomes a writer, Pedro Anchanjo, and his intellectual adversary, Nilo Argolo, a doctor known for charged ideas of prejudice. The results show that the works of Archanjo, mestizo, poor, are only recognized from interest Levenson, reputed foreign. His books mainly portray a militant work against prejudice, violence and intolerance of white about the rituals of African origin.

\section{Entradas para indexação}

PALAVRAS-CHAVE: Identidade negra. Literatura. Colonização. Mestiçagem. KEYWORDS: Black identity. Literature. Colonization. Miscegenation.

\section{Texto integral}

\section{Apresentação: a obra amadiana entre a ficção e a realidade}

Este artigo tem o objetivo de analisar a obra ficcional Tenda dos milagres, de Jorge Amado, à luz de teorias que fundamentam a discussão acerca dos intelectuais negros e sua produção teórico-crítica e, ou literária, além de discutir aspectos da crítica pós-colonial relativa à identidade negra. 0 personagem que protagoniza a obra em estudo, Pedro Anchanjo, exemplifica aqui uma militância contra a elite racista, a partir dos textos que publica. Assim, a obra, num trabalho, de certo modo, metalinguístico, configura-se como uma narrativa sobre um autor que sofre o preconceito e, através de seus textos, busca combatê-lo.

Os procedimentos metodológicos incluem a análise de conteúdo e de discurso no texto literário, através de técnicas de pesquisa como a coleta, o tratamento e a interpretação de dados. Utilizou-se o método indutivo, em que as constatações particulares levam à elaboração de generalização, a fim de tomar a obra amadiana como representante de todo um conjunto de pensamentos e atitudes, o que justifica que o corpus escolhido para esta pesquisa funcione como representação da identidade cultural pesquisada como um todo. Em virtude de a pesquisa ter caráter qualitativo, utilizou-se, também, o método dialético, compreendendo que os fatos não podem ser considerados fora de um contexto social, político, econômico etc. (LAKATOS; MARCONI, 1993).

Jorge Amado, escritor não negro, comumente utiliza-se de seus personagens para representar seu engajamento político e sua indignação quanto à segregação racial e social. Esse estilo literário que o autor adota faz com que sua obra tenha 
caráter tanto de representação social, quanto ficcional. Sobre o tema, Candido (2011, p. 13) argumenta:

Hoje sabemos que a integridade da obra não permite adotar nenhuma dessas visões dissociadas; e que só a podemos entender fundindo texto e contexto numa interpretação dialeticamente íntegra, em que tanto o velho ponto de vista que explicava pelos fatores externos, quanto o outro norteado pela convicção de que a estrutura é virtualmente independente, se combinam como momentos necessários do processo interpretativo. Sabemos, ainda, que o externo (no caso, o social) importa, não como causa, nem como significado, mas como elemento que desempenha um certo papel na constituição da estrutura, tornando-se, portanto, interno.

Também buscando compreender o texto literário, Rama (2008) afirma que, com os conceitos de cultura delineados pelos antropólogos (a exemplo de Boas, Sapir, Herskovits...), desenhou-se o complexo comportamento da literatura com singularidades culturais. Criou-se uma dupla leitura do tipo intertextual: a dos textos literários e a dos discursos, com invenções de diversas culturas testemunhando a tarefa coletiva dos homens.

Para confirmar tais assertivas, sobre Tenda dos milagres e sua relação com o contexto em que viveu o autor, o próprio Jorge Amado afirma, em Navegação de cabotagem: apontamentos para um livro de memórias que jamais escreverei:

[...] Pedro Arcanjo é a soma de muita gente misturada: o escritor Manuel Quirino, o babalaô Martiniano Eliseu do Bonfim, Miguel Santana Obá Até, o poeta Artur de Sales, o compositor Dorival Caymmi e o alufá Licutá - e eu próprio, é claro. De todos eles Arcanjo incorpora um traço, uma singularidade, a preferência, o tom de voz, o gosto da comida, o trato das mulheres, a malícia [...]. (AMADO, 1993, p. 139).

Desde o início da obra, o autor dá pistas de que a mesma ocorre numa mescla entre ficção e realidade, o que confirma a teoria de Candido (2011) quanto à natureza do texto literário e sua relação com a sociedade. Ao afirmar que o protagonista é inspirado em pessoas de seu convívio, Amado influencia o leitor a compreender sua obra não somente pelo aspecto estético, mas identificando, nas ações e caracterizações presentes no texto, uma crítica social voltada à valorização de seu povo.

Tenda dos milagres exemplifica ainda como a literatura pode ser usada enquanto suporte para a discussão acerca da diferença e subalternidade. É possível observar marcas de tradição, tradução e hibridismo que configuram as escolhas dos grupos sociais dominantes, bem como a segregação dos grupos sociais 
dominados. São suscitadas, na narrativa, estratégias de engajamento e de fortalecimento cultural através das ações de seus personagens, principalmente o protagonista, Pedro Archanjo. $\mathrm{O}$ texto evidencia as marcas de respeito à diferença $\mathrm{e}$ a crítica às hegemonias.

De fato, a relação de obras amadianas que abordam a temática negra é bastante extensa, destacando-se o aspecto religioso, sendo possível mencionar Jubiabá, Capitães da areia, Os pastores da noite, O sumiço da santa, Dona Flor e seus dois maridos, Bahia de Todos os Santos, Tenda dos milagres, entre outros. Todas as obras aí citadas contêm cenas com descrições bastante detalhadas da prática do candomblé, por exemplo, o que demonstra a vivência do autor nesse contexto.

Desse modo, a obra de Jorge Amado afirma-se e permanece não apenas como invenção, como uma construção ficcional, mas igualmente, como documento, patrimônio intangível, configurando os espaços de narrativa como um registro onde estão consignados os signos mais evidentes de nossa pluralidade cultural. (FRAGA, 2004, p. 19).

Consagra-se, assim, a obra amadiana como representante da cultura baiana, por recontar a sua história a partir de um olhar próprio, por vezes irônico, por vezes panfletário, com vistas a defender a tese da tolerância e do respeito ao diferente. As relações de poder, a hierarquia social, a opressão ao subalterno são temas sobre os quais a obra suscita o leitor a refletir.

\section{A história da colonização e seus desdobramentos na identidade negra e na literatura amadiana}

Para melhor compreender os aspectos que compõem a identidade negra no contexto amadiano, é necessário compreender a história da colonização do Brasil, incluindo o processo de escravidão que se configurou em boa parte do território. Os portugueses que se instalaram no país trouxeram da África uma quantidade até difícil de mensurar de seres humanos, com a intenção de escravizá-los, que, na verdade, foram "arrancados" de sua terra natal, apenas pelo fato de serem negros e, por isso, considerados inferiores. Fazia parte do projeto de colonização a negociação com indígenas, nem sempre pacífica, e a exploração das terras, a partir da mão-de-obra escrava negra.

Poder-se-ia dizer que todos os exemplos históricos de conquistas e invasões raciais são uniformes em seus resultados finais. A raça invasora e triunfante apropriava-se da terra e a dividia e os descendentes dessa raça constituíam-se soberanos dessa terra... [...]. (BILBAO apud MIGNOLO, 2003, p. 196). 
Compreende-se, nesse ínterim, que o tráfico de escravos não só impulsionou uma tentativa de destruição física e cultural de diversas comunidades africanas no século XVI, mas também imprimiu, em toda a história subsequente, uma interpretação cultural discriminatória, visando valorizar unicamente a etnia do colonizador, branca. 0 resultado dessas ações pode ser identificado no contexto brasileiro contemporâneo, com a ainda presente segregação da etnia afrobrasileira:

A destribalização do negro e sua fusão nas sociedades neoamericanas constituiu um dos mais portentosos movimentos de população e o mais dramático processo de deculturação da história humana. Para efetuá-lo, o europeu arrancou da África, em quatro séculos, mais de 100 milhões de negros, vitimando cerca da metade no apresamento e na travessia oceânica, mas conduzindo a outra metade para as feitorias americanas, onde prosseguiu o desgaste. Um dos efeitos cruciais dessa transladação de africanos e de sua incorporação como escravos na força de trabalho das sociedades americanas nascentes foi a implantação de uma estratificação étnica com as tensões da discriminação racial. [...] Muito da discriminação racial e social que ainda hoje inferniza os povos americanos têm suas raízes nesta bipartição que fixou, tanto nos brancos quanto nos negros e seus mestiços, rancores, reservas, temores e ascos até agora não erradicados. (RIBEIRO, 2007, p. 191).

Em Tenda dos milagres, o aspecto social é apontado como consequência do aspecto racial. A atitude militante de Pedro Archanjo no enredo do romance traduz essa parte da história nacional, enfatizando que a condição socioeconômica se sobrepõe à condição étnica:

Ildásio não lhe aceitava as teses, tampouco Toninho Lins. Este último, um cara sério, de prestígio no meio estudantil, desejava mostrar sobretudo o Pedro Archanjo grevista, de pé contra patrões, trustes e polícia; fazia da luta de classes o centro do espetáculo. "O problema racial, camaradas, é conseqüência do problema de classes" - explicava, citando autores, calmo, sem exaltar-se. "No Brasil, camaradas, negros e mulatos são discriminados em sua condição de proletários: branco pobre é negro sujo, mulato rico é branco, puro". (AMADO, 1971, p. 195).

De pensamento consoante ao de Jorge Amado, Sartre, que fora seu amigo, declarou algo que confirma a segregação velada que domina certos ambientes do país (publicado por sua esposa, Simone de Beauvoir). 0 eurocentrismo que se firmou neste ambiente fortaleceu o nocivo apagamento das demais culturas: 
Jamais vimos nos salões, nas universidades, nem nos auditórios um rosto chocolate ou café com leite. Sartre fez essa observação em voz alta durante uma conferência em São Paulo, depois se corrigiu: havia um negro na sala - um técnico de televisão. (BEAUVOIR apud GUIMARÃES, 2013, p. 36).

A crítica à hegemonia aparece também na descrição que Nilo Argolo, personagem antagonista, faz do negro enquanto bárbaro, relacionando seu comportamento à violência, como se houvesse ali uma ressignificação do entendimento que se tinha no Brasil escravocrata da relação entre o senhor e o escravo: "[...] enquanto o escravo conhece tanto a razão do senhor quanto a do escravo, o senhor conhece apenas sua própria razão e a não-razão do escravo (poderíamos aqui substituir senhor-escravo por civilização-barbarismo)" (MIGNOLO, 2003, p. 221). O personagem do médico polemiza ao atribuir a diversas características da etnia negra uma conotação diminutiva:

Você confunde batuque e samba, hórridos sons, com música; abomináveis calungas, esculpidos sem o menor respeito às leis da estética, são apontados como exemplos de arte; ritos de cafres têm, a seu ver, categoria cultural. Desgraçado deste país se assimilarmos semelhantes barbarismos, se não reagirmos contra esse aluvião de horrores. Ouça: isso tudo, toda essa borra, proveniente da África, que nos enlameia, nós a varreremos da vida e da cultura da Pátria, nem que para isso seja necessário empregar a violência. (AMADO, 1971, p. 178).

A conscientização que se pode extrair da leitura da obra está embutida no contexto em que foi produzida, e vice-versa, visto que ambas (obra e sociedade) se alimentam uma da outra. A sociedade brasileira da época, bem como a sociedade baiana, ou soteropolitana, especificamente, retratam as consequências da história do povo negro, seus costumes, sua religião:

Assim, com a imagem da religião perseguida, o negro se torna facilmente o impuro, o segmento imundo da sociedade, que é preciso extirpar e imolar a qualquer preço. Sua presença é insuportável tanto no plano moral quanto no plano físico: esse é o ponto de vista da maioria dos brancos que integram a burguesia baiana e para quem ele é, de alguma forma, a expressão da consciência má. (SALAH, 2008, p. 118).

É importante salientar que o comportamento discriminatório em tese abordado não está circunscrito apenas ao período que a obra retrata, nem ao período em que foi produzida. Tal comportamento se faz presente atualmente na sociedade brasileira como um todo. 
A segregação étnica inicial dá lugar à segregação social, também opressora, que emperra de forma significativa o fluir da vida daqueles que se encontram nessa camada da sociedade. A injustiça social e a desigualdade econômica são consequências da origem desta história escravocrata do Brasil, amplamente representadas na obra amadiana:

Assim, os brasileiros da mais nítida fisionomia racial negra que, emergindo recentemente das condições de escravidão, ainda se concentram nas camadas mais pobres não atuam social e politicamente motivados pelas diferenças raciais, mas pela conscientização do caráter histórico e social - portanto, incidental e superável - dos fatores que os lançaram nos estratos mais pobres da população. (RIBEIRO, 2007, p. 207).

Finazzi-Agrò (2013, p. 174) também argumenta sobre o encontro entre a cultura do colonizado e do colonizador, bem como seus desdobramentos:

A expansão da cultura do colonizador, em suma, esbarra com os limites impostos pela cultura do colonizado - limites porosos, permeáveis, prestes a desabar, mas que, exatamente por isso, não definem uma situação de desajuste ou de dualismo irremediável, desembocando, pelo contrário, em formas compromissórias, em produtos culturais esponjosos e reversíveis.

No âmbito das diferenças e das trocas culturais, a questão fundamental, nessa perspectiva, ficam a posse e as relações de poder entre o Eu que fala e deseja e o objeto falado/desejado questão na qual está dobrado também o problema, propriamente histórico, da relação entre passado e presente, entre o arcaico e o moderno, entre memória e esquecimento, entre tradição e inovação. Ou seja, as relações entre culturas não são apenas ditadas por uma situação de supremacia ou de dependência (o que é óbvio), mas nelas se inscreve também um projeto de comunidade, fundado sobre a reivindicação de uma autonomia, que pretende, por sua vez, uma profundidade temporal e uma autonomia territorial [...]. (FINAZZI-AGRÒ, 2013, p. 238).

O fato de Archanjo estar ligado ao culto do candomblé, naquele contexto considerado ilegal, faz com que alguns se sintam no direito de reivindicar o seu "apagamento" da história:

O culto afro-brasileiro, a prática da religião negra, o candomblé, sem autorização legal no país, esteve sempre sujeito não só à perseguição mas à repressão, quase sempre violenta, da polícia. Em 1946, com a eleição havida para a Câmara e Senado, e, a seguir, a transformação de deputados e senadores em 
constituintes, Jorge, deputado constituinte pelo Partido Comunista, foi autor de um projeto de lei, acolhido e aprovado, assegurando a liberdade religiosa no Brasil. (SANTOS, 1993, p. 79).

De forma contestatória, Archanjo continua frequentando os terreiros de candomblé, mesmo depois de desacreditar nos orixás: tudo para não deixar esmorecer o ânimo dos perseguidos e evitar o triunfo da polícia e da elite racista:

- Se não acredita mais, não acha desonesto praticar uma farsa, como se acreditasse?

- Não. Primeiro, como já lhe disse gosto de dançar e de cantar, gosto de festa, antes de tudo de festa de candomblé. Ademais, há o seguinte: estamos numa luta, cruel e dura. Veja com que violência querem destruir tudo que nós, negros e mulatos, possuímos, nossos bens, nossa fisionomia. Ainda há pouco tempo, com o delegado Pedrito, ir a um candomblé era um perigo, o cidadão ariscava a liberdade e até a vida. (AMADO, 1971, p. 316).

O desrespeito à religião do outro, em lugar da valorização e consideração da religião católica como única possível se firmam no enredo da obra. 0 delegado Pedrito, outro personagem de destaque em Tenda dos milagres, está no comando de diversas invasões a terreiros de candomblé que a obra retrata e que ocorreram de fato na história do lugar:

- Ouça, cabra ruim: santo de igreja faz milagre, por isso é santo. Esses santos de vocês só fazem barulho, são uns santos de merda. No dia que eu ver um milagre desses putos, nesse dia me demito do cargo [...]. Daqui a poucos dias vai fazer seis anos que baixo pau no candomblé, já acabei com quase todos, vou acabar com o resto de uma vez. Nesse tempo todo nunca vi milagre de orixá. Muito falatório e só. (AMADO, 1971, p. 305).

A não aceitação daquela realidade pelo protagonista faz com que ele tenha uma iniciativa insubordinada quanto à opressão do delegado: "Pedro Archanjo propôs a organização de uma brigada de capoeiristas para guardar o Terreiro e enfrentar os esbirros do delegado" (AMAD0, 1971, p. 307).

A busca pela liberdade, negada ou constantemente interrompida pela condição sócio-histórica do povo descrito na obra amadiana, é constantemente retratada. A transgressão e a resistência estão sempre presentes na trama, através da insatisfação experienciada pelos personagens, e do discurso que busca semear um novo comportamento, uma nova vida. Acerca desse aspecto, Santos (1993, p. 199) confirma: 
A preocupação maior do romancista, como transparece a partir de certa fase de sua vida e de sua obra, é com o destino do homem e o mundo em que amanhã irá ele viver. [...] Seja o escrito do romancista, com o discurso político ou sem ele, através do engajamento nos movimentos políticos ou não, como militante ativo do Partido Comunista ou não, mas, sobretudo, com as ilimitadas possibilidades de sua arte, luta com as armas de que dispõe - pela liberdade do homem, contra a opressão, pelo desenvolvimento econômico-social que lhe proporcione melhor qualidade de vida, pela suficiência de recursos materiais, contra a penúria e a fome; pela alegria, contra a tristeza, pelo otimismo, e a confiança nesse futuro, com que se deve sonhar, mais digno que o presente.

O tema da liberdade em Jorge Amado supera a liberdade física, abarcando também a liberdade religiosa, política, social. Suas obras, e também Tenda dos milagres, interpretam o presente opressor com vistas a prepará-lo para um futuro melhor, a partir da militância de seus personagens:

Agora é diferente: o velho bebe, ávido, cada palavra do moço estudante, árdego mestiço a acusar o racismo, juventude impetuosa a vislumbrar o futuro. Desce do banco: nessa guerra é veterano, nela combate há muitos anos, em suas trincheiras consumiu a vida. (AMADO, 1971, p. 357).

Tenta dos milagres pode ser considerada uma crônica da vida baiana, do cotidiano de seu povo, suas angústias, suas lutas, suas conquistas. Jorge Amado escreve sobre Pedro Archanjo, que, por sua vez, escreve sobre a Bahia de Jorge. Esse itinerário dialético permitiu que se construísse uma obra ímpar, no que se refere ao conteúdo social e aos desdobramentos que ela possa gerar:

Quando iniciara o livro, a imagem pernóstica de determinados professores e o eco das teorias racistas estavam presentes em seu espírito e influíam nas frases e palavras, condicionando-as e limitando-lhes a força e a liberdade. À proporção, porém, que páginas e capítulos foram nascendo, Pedro Archanjo esqueceu professores e teorias, não mais interessado em desmenti-los numa polêmica de afirmações para a qual não tinha sequer preparo, e sim em narrar o viver baiano, as misérias e as maravilhas desse quotidiano de pobreza e confiança; em mostrar a decisão do perseguido e castigado povo da Bahia, de a tudo superar e sobreviver, conservando e ampliando os bens da dança, do canto, do metal, do ferro, da madeira, bens da cultura e da liberdade recebidos em herança nas senzalas e quilombos. (AMADO, 1971, p. 164). 
O romance critica a postura colonialista e busca valorizar a identidade negra e, no mesmo bojo, a mestiçagem. A ironia utilizada por Amado para tratar o tema suscita a reflexão acerca das teorias racistas, que se configuram como um dado atrelado à realidade e que são redimensionados no texto ficcional.

\section{Pedro Archanjo: um mestiço escritor}

Como forma de representação do trabalho intelectual não europeu e não acadêmico, Pedro Arcanjo desponta no texto como autor de obras impressas, mas que sofrem a não valorização por conta da sua origem não acadêmica, geográfica, economicamente difícil, mestiça. Na trama, por muitos anos, as obras não despertaram o interesse dos brasileiros. Só passam a ser (re)conhecidas e valorizadas a partir do interesse de James D. Levenson, um renomado estrangeiro.

Após esse impulso externo, Pedro Archanjo passa a ser considerado um símbolo de resistência da cultura afro-brasileira: mestiço, pobre, bedel da Faculdade de Medicina da Bahia, um estudioso apaixonado de sua gente, publicando livros sobre a mestiçagem genética e os sincretismos simbólicos do povo baiano. Suas obras são referência no combate ao racismo e à repressão à cultura afro-brasileira. Nesse trabalho de metaficção, Jorge Amado aproveita para inserir no enredo o seu próprio trabalho, assim como de seus amigos também escritores, como afirmado em Navegação...:

Não vou opinar sobre a obra de Archanjo, hoje acima de qualquer debate ou restrição; ninguém se atreve a negá-la, após sua definitiva consagração por Levenson, e as várias traduções, o sucesso em toda parte. Ainda ontem li no serviço telegráfico dos jornais: 'Archanjo publicado em Moscou com louvores do Pravda'. (AMADO, 1971, p. 22).

A popularização das obras de Pedro Archanjo somente após a apreciação de um estrangeiro retrata um comportamento de supervalorização do que vem de outros países (leia-se europeu e, ou norte-americano), que ainda hoje ocupa as preferências do brasileiro em diversos aspectos:

Ora, de súbito, não só os jornalistas, mas os poderes públicos, a Universidade, os intelectuais, o Instituto, a Academia, a Faculdade de Medicina, os poetas, os professores, os estudantes, a classe teatral, a numerosa falange da etnologia e da antropologia, o Centro de Estudos Folclóricos, a turma do turismo e outros desocupados, todos se deram conta de que possuíamos um grande homem, um autor ilustre, e o desconhecíamos, não lhe dávamos serventia sequer em discursos, relegando-o ao anonimato mais 
completo, sem nenhuma promoção. Começou então a corrida em torno de Archanjo e de sua obra. Muito papel, muita tinta e muito espaço em jornal foram gastos, a partir da entrevista de Levenson, para saudar, analisar, estudar, comentar, louvar o injustiçado escriba. Era necessário tirar o atraso, corrigir o erro, apagar o silêncio de tantos anos. (AMADO, 1971, p. 36).

Apesar do sucesso da obra de Pedro Archanjo, uma segunda onda de não aceitação surgiu: a mesma recai sob a mira da elite "branqueada" da Bahia, sendo perseguida. Em seu entorno, sinais de preconceito, violência e intolerância dos brancos diante dos rituais de origem africana se mostravam com frequência.

A militância de Pedro Archanjo se configura a partir de ações que visem a conscientização da população que a ele se assemelha, tanto em termos étnicos, quanto pelas razões sociais. A postura de luta se alicerça a partir do conclame aos estudantes, tradicionalmente considerados importantes atores sociais em suas inconformidades e efetivos em suas ações:

- Perigo e grande. Esse seminário, com uma temática explosiva mestiçagem e apartheid é perigosíssimo foco de agitação, dele pode nascer um incêndio de proporções imprevisíveis, meus caros. Pensem nos rapazes da Universidade, nos meninos dos ginásios. Não lhes nego razão em certos reclamos e o nosso jornal o tem dito, corajosamente. Mas, convenhamos que qualquer pretexto serve para os agitadores infiltrados no meio estudantil, para os profissionais da desordem e da baderna. (AMADO, 1971, p. 143).

Assim, como afirmou o próprio Jorge Amado e como muitos críticos de sua obra observam, a construção do personagem Pedro Archanjo fora inspirada na vida do seu criador. A participação da Archanjo no culto do candomblé, sua relação com as mulheres, a defesa da mestiçagem e seu engajamento político revelam muito do comportamento amadiano:

[...] Em primeiro lugar - parece haver uma quase total unanimidade dos críticos que analisaram a obra amadiana - por suas qualidades, sua vocação, sua cultura e sua existência, Pedro Archanjo seria não somente a representação do romancista ou seu alter ego, como também o símbolo indubitável do mestiço baiano. Em segundo lugar, porque ele pode ser considerado de uma certa forma como o protagonista de um romance à thése, encarregado de expressar o engajamento de Jorge Amado na eterna discussão relativa à mestiçagem e aos seus correlatos igualmente contestáveis e contestados de "civilização da Bahia" e "humanismo baiano”. (SALAH, 2013, p. 59). 
A valorização do mestiço e a negação da autoridade do colonizador na obra amadiana também podem ser interpretadas a partir de um novo arcabouço epistemológico, que surge no mesmo contexto em que se desenvolvem as críticas pós-coloniais. Dando à linguagem a importância que lhe é devida, tais estudos trazem terminologias que buscam atender às novas demandas, que não mais aceitam ser caracterizadas a partir de formatos tradicionalmente "colonizadores". Surge, então, uma espécie de anarquismo epistemológico, no sentido feyerabendiano, mas que, ao mesmo tempo, configura-se como uma nova forma de pensar, também direcionada a partir de um método, mesmo que inovador:

A pós-colonialidade e a abordagem do sistema-mundo partilham entre si uma crítica ao desenvolvimentismo, às formas eurocêntricas de conhecimento, às desigualdades entre os sexos, às hierarquias raciais e aos processos culturais/ideológicos que fomentam a subordinação a periferia no sistema-mundo capitalista. (GROSFOGUEL, 2010, p. 470).

A possibilidade de interpretar a obra amadiana a partir de uma teoria contemporânea faz com que se perceba a atualidade de sua escrita, da temática que a mesma aborda, construindo sua permanência na história do país. A escrita militante de Pedro Archanjo (e do sujeito de enunciação) retoma o passado a fim de melhor posicionar o contexto no futuro: "[...] tudo já terá se misturado por completo e o que hoje é mistério e luta de gente pobre, roda de negros e mestiços, música proibida, dança ilegal, candomblé, samba, capoeira, tudo isso será festa do povo brasileiro, música, balé, nossa cor, nosso riso, compreende?" (AMAD0, 1971, p. 318).

A literatura amadiana, de modo geral, representa a permanência dessa discriminação, quando suas narrativas utilizam a voz da identidade negra que necessita reivindicar sua dignidade. Em Tenda dos milagres, o destaque que se dá ao personagem Nilo Argolo ocorre principalmente pelo fato de suas atitudes descritas chocarem o público leitor pela arbitrariedade como tal médico busca impor a aplicação de suas teorias racistas:

Desta vez a besta do Nilo Argolo se excedeu. [...] - Nem na América do Norte se cogitou de legislação tão brutal. O Monstro Argolo ganhou até para as piores leis, as mais odiosas, de qualquer Estado sulista, daqueles mais racistas dos Estados Unidos [...]. Pedro Archanjo levou a brochura, pequeno livro em cujas páginas o professor de Medicina Legal resumia e ordenava suas conhecidas idéias e teses sobre o problema de raças no Brasil. A superioridade da raça ariana. A inferioridade de todas as demais, sobretudo da negra, raça em estado primitivo, sub-humano. 0 perigo maior, o anátema lançado contra o Brasil, monstruoso atentado: a criação de uma sub-raça no calor dos trópicos, subraça degenerada, incapaz, indolente, destinada ao crime. Todo o nosso atraso devia-se à mestiçagem. 0 negro ainda poderia ser 
aproveitado no trabalho braçal, tinha a força bruta dos animais de carga. Preguiçoso e salafrário, o mestiço, porém, nem para isso servia. Degradava a paisagem brasileira, apodrecia o caráter do povo, empecilho a qualquer esforço sério no sentido do progresso, "do progredimento". [...] Só um corpo de leis, resultante do patriotismo dos senhores parlamentares, impondo a mais completa segregação racial, poderia ainda salvar a Pátria do abismo para onde rolava impelida pela mestiçagem "degradada e degradadora". (AMADO, 1971, p. 319).

O que se vê a partir da caracterização do personagem Nilo Argolo é que a etnia negra é vista apenas como um utilitário, pelo trabalho que é capaz de desempenhar, enquanto o povo mestiço, tanto quanto discriminado, é relegado a menor valia. A força do discurso científico é em tal contexto utilizada para impor credibilidade, visto que os argumentos são advindos da figura de um médico:

Incorporados, originalmente, às suas sociedades como escravos os negros emergiram para a liberdade como a parcela mais pobre e mais ignorante, incapaz de integrar-se maciçamente nos modos de vida modernos concentrando-se nas camadas mais marginalizadas, social e politicamente, da vida nacional. A miscigenação, atuando ao longo de séculos, fez das camadas mestiças de negros e brancos uma das matrizes genéticas fundamentais das populações neo-americanas [...]. (RIBEIRO, 2007, p. 191).

Funcionando como uma espécie de evolução terminológica do mestiço, o híbrido é também analisado por Finazzi-Agrò (2013, p. 241), que opõe "uma" cultura nacional em oposição à afirmação das diferenças:

O tema secular das relações entre margem e centro, a questão da dinâmica dos fluxos e refluxos culturais é, como se vê, colocada em um contexto problemático - "flutuante", justamente - no qual a homogeneidade das culturas nacionais se sublinha, por outro lado, o hibridismo na articulação das diferenças, o entrelugar, o inbetween que se cava no interior de uma situação de acumulação de lugares e tempos heterogêneos e plurais.

De modo semelhante, Amado "profetiza" a solução para os problemas sociais do país a partir da valorização do mestiço: "Se o Brasil concorreu com alguma coisa válida para o enriquecimento da cultura universal, foi com a miscigenação - ela marca nossa presença no acervo do humanismo, é a nossa contribuição maior para a humanidade" (AMAD0, 1971, p. 141).

A valorização da cultura local, da diferença, como o fez Jorge Amado em muitos de seus romances, é também sugerida por Gilberto Freyre, quando explicita 
que as particularidades de cada povo devem ser observadas para que se possa assumir atitudes benéficas:

O mundo ainda não está preparado para ser um único mundo. A verdade é que as nações sozinhas e isoladas com seus nacionalismos intolerantes estão se tornando arcaicas. Os antropólogos, os sociólogos e os estadistas do mundo iberotropical em geral e do luso-tropical em particular deveriam estudar e reconhecer o moderno conceito de área. Dentro dos limites da estrutura dos conceitos regionais antigos e dos conceitos ecológicos modernos, os homens do mundo iberotropical devem estudar seus problemas, suas heranças, suas características, suas técnicas e suas soluções comuns: soluções que, para serem efetivas, devem ser ibero-tropicais nos seus propósitos e instrumentos. (FREYRE, 2003, p. 461).

Há de se considerar a mestiçagem ou a transculturação de forma positiva, enquanto aspecto que conceitua as diferenças, as caracterizações não previamente definidas, "enformadas", inseridas em regras normatizadas, criadas antes de sua existência. 0 espaço do híbrido é o espaço do entrecruzamento de opostos, que se fundem formando um todo novo:

Que se lhe chame de mestiçagem ou de transculturação, esse lugar neutro é, em todo caso, a dimensão na qual o polimorfismo brasileiro, simbolizado por Macunaíma, tende a descarregar as suas tensões. Lugar, de fato, que, justamente por não ser nem uma coisa nem outra e sendo, ao mesmo tempo, tanto uma coisa quanto outra (segundo o ambivalente significado da sua etimologia latina nec-uter), surge como espaço de compromisso, de mediação, em que se resolvem, sem se dissolver as múltiplas contradições que caracterizam essa realidade (Sul/Norte, costa/interior, donos/escravos, branco/negro/indígena....). (FINAZZI-AGRÒ, 2013, p. 160).

0 texto amadiano pode funcionar como ilustração dos argumentos de Finazzi-Agrò, visto que a narrativa se compromete em caracterizar o povo baiano em sua cultura diversa, não moldada, múltipla:

a preservação de costumes e tradições, a organização de sociedades, escolas, desfiles, ranchos, ternos, afoxés, a criação de ritmos de dança e canto, tudo quanto significa enriquecimento cultural adquire a importância de verdadeiro milagre que só a mistura de raças explica e possibilita. Da miscigenação nasce uma raça de tanto talento e resistência, tão poderosa, que supera a miséria e o desespero na criação quotidiana da beleza e da vida. (AMADO, 1971, p. 292). 
A "infidelidade" étnica configura-se, assim, como a atitude que melhor condiciona o povo baiano enquanto mestiço, por aglomerar identidades culturais, sem excluí-las. Para o mestiço, como Pedro Archanjo, não há antagonismos culturais: em sua militância decolonial, há a convivência dos diversos:

\begin{abstract}
O renascimento colonialista engendra por sua vez uma nova sociedade, a dos mestiços, cuja principal característica é o fato de que a noção de unidade sofre reviravolta, é contaminada em favor de uma mistura sutil e complexa entre o elemento europeu e o elemento autóctone - uma espécie de infiltração progressiva efetuada pelo pensamento selvagem, ou seja, abertura do único caminho possível que poderia levar à descolonização. (SANTIAGO, 2000, p. 15).
\end{abstract}

A obra também dá margem ao debate acerca da valorização da cultura erudita em oposição à cultura popular, em virtude da forma como o autor (e seu personagem protagonista) busca retratar a experiência do intelectual tradicionalmente prestigiado pela academia e aquele que detém uma forma de conhecimento não reconhecida pela elite.

\title{
Considerações finais: a contribuição de uma obra engajada
}

O comportamento assumido pelo personagem principal da obra Tenda dos Milagres exemplifica uma espécie de anti-herói, por se configurar seu protagonista com uma trajetória contra-hegenônica. Pedro Archanjo assume o papel de "soldado" que luta contra o preconceito, ou até mesmo contra a violência vivida pelo povo proveniente da África, através da militância, pela ação intelectual.

Sobre o papel do intelectual, do militante, de falar, escrever, dizer, há a ideia de que essa produção e divulgação de pensamento contestatório causa incômodo aos tradicionalmente dominadores, como afirma Santiago (2000, p. 16): "O silêncio seria a resposta desejada pelo imperialismo cultural, ou ainda o eco sonoro que apenas serve para apertar mais os laços do poder conquistador. Falar, escrever, significa falar contra, escrever contra".

A identidade negra, verdadeira protagonista do romance aqui analisado, assim como de várias outras obras amadianas, funciona, nesse caso, como uma representação do comportamento decolonial, que questiona a subalternidade a ela delegada pela história iniciada com a escravidão, e ao mesmo a assume de forma contestatória, reivindicatória, considerando o status híbrido não uma fraqueza ou impureza, mas uma rica forma de transculturação, no sentido de enriquecimento identitário.

A literatura amadiana, de modo geral, para além do deslumbramento estético, é também dotada de uma força que impulsiona mudanças de 
comportamento, de perspectivas. Aquele que a lê, como a toda obra engajada, passa a refletir sobre as atitudes de seus personagens que, de alguma forma, muitas vezes a partir do recurso da ironia, representam uma denúncia ao comportamento humano segregador, tanto no aspecto étnico, quanto social, de gênero etc.: "Lutávamos por uma literatura brasileira que, sendo brasileira, tivesse um caráter universal; por uma literatura inserida no momento histórico que vivíamos, e que se inspirasse em nossa realidade, a fim de transformá-la" (AMADO apud SANTOS, 1993, p. 59).

Tenda dos milagres torna-se uma representação ficcional de uma realidade cultural recorrentemente marginalizada e que tem na literatura um espaço aberto para a discussão no âmbito social. Através desse recurso, obtém-se o direito de ter voz e espaço de engajamento em ações sociais para transformar a realidade através da luta pelos direitos trabalhistas, e pela organização e sistematização de processos de conscientização pelo fortalecimento cultural e identitário.

\section{Referências}

AMADO, Jorge. Tenda dos milagres: romance. 9. ed. São Paulo: Martins, 1971. Col. Obras ilustradas de Jorge Amado. XVIII.

AMADO, Jorge. Navegação de cabotagem: apontamentos para um livro de memórias que jamais escreverei. Rio de Janeiro: Record, 1993.

CANDIDO, Antonio. Literatura e sociedade: estudos de teoria e história literária. 12. ed. Rio de Janeiro: Outro Sobre Azul, 2011.

FINAZZI-AGRÒ, Ettore. Fronteiras, cruzamentos, transgressões; Economia da modernidade: prodigalidade e pobreza. In: Entretempos. Mapeando a história da cultura brasileira. São Paulo: Ed. Unesp, 2013. p. 131-185; 235-217.

FRAGA, Myriam. O documento e a fiç̧ão. In: OLIVIERI-GODET, Rita; PENJON, Jaqueline (Org.). Jorge Amado: leituras e diálogos em torno de uma obra. Salvador: FCJA, 2004. p. 19-31.

FREYRE, Gilberto. Uma visão quase apologética do comportamento hispânico ou ibérico nos trópicos. In: Estado, 2003. p. 427-462. Palavras repatriadas. Brasília: Ed. UnB; São Paulo: imprensa Oficial do

GROSFOGUEL, Ramón. Para descolonizar os estudos de economia política e os estudos póscoloniais: transmodernidade, pensamento de fronteira e colonialidade global. In: SOUSA SANTOS, Boaventura de; MENESES, Maria Paula (Org.). Epistemologias do Sul. São Paulo: Cortez: 2010. p. 455-491.

GUIMARÃES, Antonio Sérgio Alfredo. A recepção de Fanon no Brasil e a identidade negra. In: ALMEIDA, Julia; MIGLIEVICH-RIBEIRO, Adélia; GOMES, Heloísa Toller (Org.). Crítica pós-colonial. Panorama de leituras contemporâneas. Rio de Janeiro: 7Letras, 2013. p. 33-54.

LAKATOS, Eva Maria; MARCONI, Maria de Andrade. Metodologia do trabalho científico. São Paulo: Atlas, 1993. 
MIGNOLO, Walter. Compreensão humana e interesses locais. In: Histórias locais, projetos globais. Colonialidade, saberes subalternos e pensamento liminar. Belo Horizonte: UFMG, 2003. p. 181-238.

RAMA, Ángel. Literatura e sociedade; Algumas sugestões de trabalho para uma aventura intelectual de integração. In: . Literatura, cultura e sociedade na América Latina. Belo Horizonte: Ed. UFMG, 2008. p. 167-182; p. 183-192.

RIBEIRO, Darcy. As Américas e a civilização. Processos e causas do desenvolvimento desigual dos povos americanos. São Paulo: Cia. das Letras, 2007.

SALAH, Jacques. A Bahia de Jorge Amado. Salvador: Fundação Casa de Jorge Amado, 2008. (Casa de Palavras).

SALAH, Jacques. Jorge Amado e a mestiçagem ou Pedro Archanjo, o homem do futuro. In: FRAGA, Myriam; FONSECA, Aleilton; HOISEL, Evelina. Jorge Amado: 100 anos escrevendo o Brasil. Salvador: Casa de Palavras, 2013. p. 59-64. v. 1.

SANTIAGO, Silviano. O entre-lugar do discurso latino-americano. In: . Uma literatura nos trópicos. Ensaios sobre dependência cultural. Rio de Janeiro: Rocco, 2000. p. 9-26.

SANTOS, Itazil Benício dos. Jorge Amado: retrato incompleto. Rio de Janeiro: Record, 1993.

\section{Para citar este artigo}

NASCIMENTO, Aline Santos de Brito. Tenda dos milagres: o intelectual negro e a militância contra a elite racista. Miguilim - Revista Eletrônica do Netlli, Crato, v. 7, n. 1, p. 193-209, jan.abr. 2018.

\section{A autora}

Aline Santos de Brito Nascimento é doutora em Letras - Literatura pela Universidade Federal do Espírito Santo, mestre em Cultura \& Turismo Interinstitucional UESC/UFBA - Universidade Estadual de Santa Cruz e Universidade Federal da Bahia (2003), especialista em Literatura Comparada e licenciada em Letras e Artes pela Universidade Estadual de Santa Cruz (1999). Professora Assistente da Universidade do Estado da Bahia. Pesquisadora nas áreas de Letras, literatura, metodologia da pesquisa, produção de texto, língua inglesa, cultura, música e revisão textual. Membro do Grupo de Pesquisa GEICEL - Grupo de Estudos Interdisciplinares em Cultura, Educação e Linguagens - Linha de Pesquisa - Literatura: crítica, memória, cultura e sociedade. 